\title{
COMPETITIVE PRIORITIES AND STRATEGIC ALIGNMENT AS MEDIATORS IN THE RELATIONSHIP BETWEEN COMPANIES IN THE BRAZILIAN AUTOMOTIVE SUPPLY CHAIN
}

\author{
W.R. Garo Jr. ${ }^{1 *} \&$ M.R.N. Guimarães ${ }^{2}$
}

\section{ARTICLE INFO}

\section{Article details}

Submitted by authors 17 Jun 2017

Accepted for publication 27 Jan 2018

Available online $\quad 31$ May 2018

\section{Contact details}

* Corresponding author

wagner.garo@ifsp.edu.br

Author affiliations

1 Federal Institute of Education, Science and Technology of São Paulo, Brazil

2 Department of Industrial Engineering, Federal University of São Carlos, Brazil

\section{DOI}

http://dx.doi.org/10.7166/29-1-1791

\section{ABSTRACT}

This study aimed to assess how the search for strategic alignment and competitive priorities influences the relationship between companies in the Brazilian automotive supply chain. To achieve this, qualitative research was conducted using an integrated case study in the automotive segment of companies that had business relationships with each other. The following elements were studied: an automaker, three automotive systems suppliers, and three second-tier suppliers. The results show that there is a strategic alignment in the chain, mainly driven by the automaker and the systems suppliers, and that competitive priorities shape the forms of the relationships between companies in the automotive supply chain.

\section{OPSOMMING}

Hierdie studie se doel is om te bepaal hoe die soeke vir strategiese belyning en kompeterende prioriteite die verhouding tussen maatskappye in die Brasiliaanse voertuig voorsieningskettingbedryf beïnvloed. Om hierdie doel te bereik is kwalitatiewe navorsing geloods deur middel van 'n geïntegreerde gevallestudie in die voertuigsektor, spesifiek van firmas wat verhoudinge met mekaar het. Die volgende elemente is bestudeer: ' $n$ voertuigvervaardiger, drie voertuigstelsel verskaffers en drie sekondêre verskaffers. Die resultate toon dat daar inderdaad 'n strategiese belyning in die voorsieningsketting is en dat kompeterende prioriteite die verhoudings tussen firmas in die ketting beïnvloed.

\section{INTRODUCTION}

The current global economic scenario characterised by globalisation, smaller distances, greater speed of information and, therefore, greater competition among companies. This degree of competition means that organisations must seek new alternatives to increase their competitiveness, rather than operating in networks or chains. The integrated operation of a supply chain, both operationally and strategically, can increase the participants' competitive advantage and stimulate competition - no longer between companies, but now between supply chains [1], [2].

The automotive sector is one of the most representative in terms of supply chains, considering the complexity of the product and the high level of outsourcing. In Brazil, this industry was the 10th largest producer of automobiles in the world and employed 1.3 million people in 2016 [3], justifying its importance in the Brazilian economic scenario. This sector has undergone many changes in recent decades, with the emphasis on reducing the number of suppliers in an attempt to stimulate an effective relationship between partners, exchange of knowledge, and stimulation of innovations and long-term relationships [4]. In this context, the strategic and competitive priorities can act as mediators in this relationship process, stimulating (or otherwise) the creation of partnerships among participants in the automotive chain. From this scenario arises the motivation for the present research, characterised by the following question: "How do the search for strategic alignment and 
the competitive priorities of companies in the automotive sector influence the relationships among the members of the supply chain?"

Thus this article seeks to demonstrate how strategic alignment occurs, what competitive priorities are addressed in the segment studied, how these priorities interfere with or mediate in the relationship between companies, and whether or not they favour integration between the components of the supply chain of automotive suppliers. The article begins with an initial theoretical review of the subject. The research method used, the results, the discussions, the analysis according to the theory, and the final considerations are presented later.

\section{THEORETICAL REVIEW}

\subsection{Strategic and competitive priorities}

Today's competitive environment compels the management of organisations to make the search for competitive advantage one of their fundamental tasks [5]. One cannot think of competitive advantage without referring to the study of strategy. The strategy theme is classically associated with military exercises, especially in the secular text of Sun Tzu, who described this term as synonymous with the choice of advantageous paths [6].

In the field of business strategy, Porter [7] says that the aim of a strategy is to create a fit between the activities of a company and to integrate them, because success depends on doing several things well, not just a few. Wheelen and Hunger [8] define 'strategy' as the master plan to achieve the goals and mission of a corporation. Almeida, Machado Neto and Giraldi [9] define 'strategy' as the identification and establishing of a set of objectives and goals, as well as patterns and actions, through the allocation of resources and competencies, and through considering the influences, the forces, and the will of the organisation and its leaders to carry them out. Mintzberg, Lampel, Quinn and Ghoshal [10] demonstrate the difficulty and, perhaps, the advantage of not showing so much concern for a closed definition of the strategic theme, but rather in understanding the complexity. A strategy can also be represented by competitive priorities. Chase, Jacobs and Aquilano [11] emphasise that the choices made by clients, and the strategies established by corporations, guide the positioning of companies in order to face competition. This positioning is conducted according to competitive dimensions or priorities. Competitive priorities are related to the competitive performance criteria that the production function - that is, the maximum output obtainable from a given set of inputs - can adopt to fit the corporation's business strategy [12]. Jabbour [13] considers competitive priority as a way of translating the customers' needs that the company must meet into performance targets for the production function. The author identifies, in Table 1, the competitive priorities commonly addressed in the theory, with their respective meanings. These definitions will be used in this research.

Table 1: Competitive priorities and their meanings (Adapted from Jabbour [13], p.37).

\begin{tabular}{|c|l|}
\hline Competitive priority & \multicolumn{1}{|c|}{ Meanings } \\
\hline Cost & $\begin{array}{l}\text { Offer products with lower price than competitors; reduce } \\
\text { production costs. }\end{array}$ \\
\hline Quality & $\begin{array}{l}\text { Offer products with features and functionalities that are superior to } \\
\text { those of competitors, or are not available from competitors; offer } \\
\text { products that are produced according to previously established } \\
\text { standards; offer products with low defect rates; offer durable } \\
\text { products. }\end{array}$ \\
\hline Flexibility & $\begin{array}{l}\text { Implement rapid changes in product design; implement rapid } \\
\text { changes in the variety of products; rapid introduction of new } \\
\text { versions of existing products or of brand new products; offer wide } \\
\text { range of products; changes in production volumes in response to } \\
\text { changing demand. }\end{array}$ \\
\hline Delivery & \begin{tabular}{l} 
Shortest delivery time possible; orders and dates of delivery. \\
\hline
\end{tabular} \\
\hline
\end{tabular}

Thürer, Godinho Filho, Stevenson and Fredendall [14] confirmed the theoretical propositions that identify cost, quality, flexibility, and delivery as priorities. Peng, Schroeder and Shah [15], in a study of 238 companies in the electronics, machinery, and transportation industries, found that competitive priorities - especially cost, flexibility, and innovation - can play a mediating role 
through innovation capacity and in their capacity to implement improvements in operational performance. González-Benito and González-Benito [16] affirm that the best results come from companies that combine quality, reliability, and flexibility as their priority objectives, and view the reduction of costs as of secondary importance. Kroes and Ghosh [2], in research into American manufacturing companies, also found an alignment of competitive priorities among companies in a supply chain.

The degree of customer demand reflects directly on the competitiveness of companies. Hill [17] describes two dimensions that are important in achieving competitive success: order-qualifying criteria, and order winners. The first is represented by criteria associated with the pre-requirements for doing business, and the second when differentiating the product or service from that of the competition [17].

\subsection{The automotive supply chain}

Supply chains can be described as business networks formed by customers and suppliers. The organisation of a supply chain allows access to competencies and complementary resources of the company through integration of the companies throughout the network [18].

Strategic alignment between supply chain strategy and business strategy is important in achieving competitive advantage [19]. Alves Filho, Cerra, Maia, Sacomano Neto and Bonadio [20] synthesise the main assumptions of supply chain management, grouping them into four related subsets: competitive environment; strategic alignment of organisations and sharing of earnings; structure of the chain; and the relationships between the companies in the chain. Reinforcing this view, the authors remark that supply chain companies have their strategies properly aligned in order to face competition and generate gains for all their links. Brito and Mariotto [21], on the other hand, in a study of relationships in the supply chain in the area of technology and information, showed that collaboration positively influences the results of the chain - including, for example, mutual assistance in resolving problems.

In the case of the automotive industry, it is noted that it is currently seeking to maintain networks with fewer suppliers, longer-term relationships, and greater integration with suppliers, so that all participants actively contribute to increase the automakers' competitiveness [22]. Lockstrom, Schadel, Moser and Harrison [23] assess the concept of the supply chain for the automotive industry, considering it unlikely that a single company would be able to produce all the components of a car. Wiengarten, Humphreys, Cao, Fynes and McKittrick [24] note that the current challenges of the automotive supply chain are inventory reduction and mass customisation. Joshi, Nepal, Rathore and Sharma [25] indicate that it may be a mistake to interpret the automotive chain as being the sole decision-maker, as being the chain's strongest link. Alves Filho et al. [26] note that the assemblers have proposed some changes to the supply chain arrangements, and to the pattern of the automakersupplier relationship.

For Bailey [27], the current scenario is characterised by an increase in the productive scope of the first-level suppliers of the automotive chain, with the assembly of the vehicle the only function left to the automaker. This situation has a cascade effect, causing system designers to transfer some of their responsibilities to smaller partners at lower levels of the supply chain, allowing them to focus more on the design and fabrication of automotive systems [27]. Pereira and Geiger [28] comment that this outsourcing movement can stimulate small and medium-sized companies to participate in the automotive chain. Lambert and Cooper [1] propose a view of the network supply chain that breaks the concept of hierarchy that is normally applied to the supply chain. This proposition reinforces the importance of collaborative relationships in the chain, guided by the focal company. The strength of the Lambert and Cooper [1] model is to break the chain concept into a logical hierarchy, grouping their components horizontally and strengthening the integration of the key macroprocesses of the business [29], so that they are aligned with the requirements of the focal company. Figure 1 adapts the model of Lambert and Cooper [1] to the case of the automotive supply chain - the focus of the present study. 


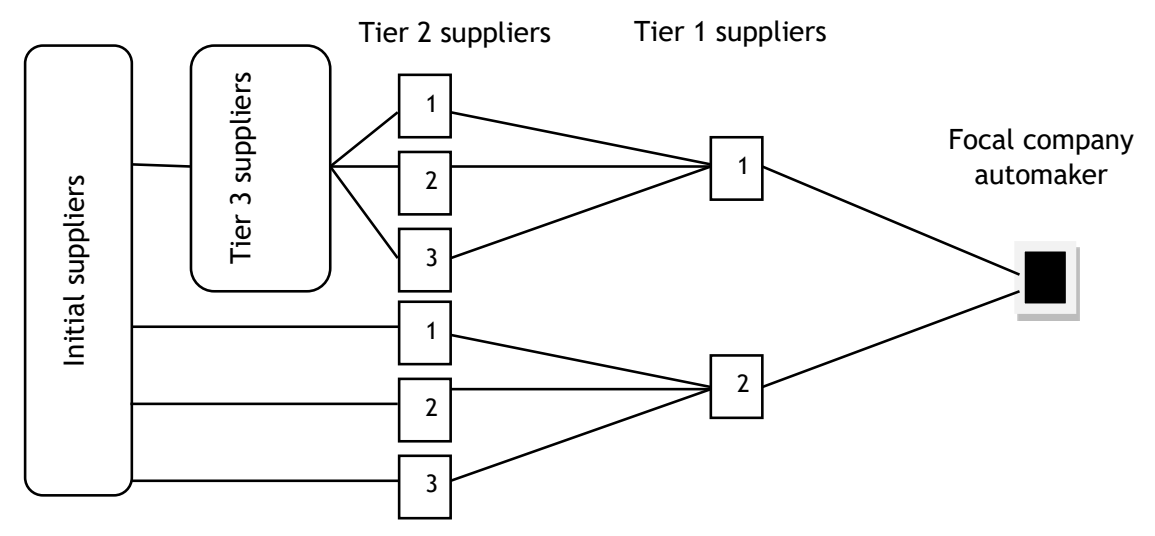

Figure 1: Automotive chain management structure: network of companies

Alves Filho, Nogueira and Bento [22], in a survey of car engine manufacturers in Brazil, find that the most relevant competitive priorities are flexibility, cost, quality, and reliability of delivery. Their research also presents other results, including suppliers being located closer to one another and the adoption of lean manufacturing practices in order to support the identified competitive priorities. In a study of auto parts industries in São Paulo, Brazil, Guimarães, Teodoro Filho, Lara and Saltorato [30] identified the influence exerted by clients, implying a strategic alignment along the supply chain. For those authors, the predominant competitive priorities were quality and delivery, in that order. They also identified that clients exert a great influence on quality management, and that companies seek to reinforce their competitive priorities through the selection and evaluation of suppliers. Dyer and Nobeoka [31] agreed, noting the importance of suppliers to the automotive producer, and stating that about 70 per cent of the value of a vehicle is generated by the suppliers of automotive components and systems. These same authors describe how Toyota has created an effective network of suppliers to share knowledge. This feature is attributed in part to the strong identity of their networks, and because of the norms of the network that support coordination, communication, and learning. The good results of a more proactive interaction between customers and suppliers can also be seen in a survey conducted by Prahinski and Benton [32] of 139 first-level suppliers in the US automotive industry. The results of this research indicate that collaborative communication is highly valued, and shows itself in a positive influence on the supplier in the simple process of communicating about the supplier' performance.

Rensburg [33] investigated small and medium-sized businesses that have customer-supplier relationships within a supply chain. The results show a broadly positive influence on the competitive advantage of companies that had a relationship of information exchange with their clients. In a survey of US and Japanese automotive suppliers, Dyer and Hatch [34] found that Toyota's knowledge-sharing supported a much better outcome than the supplier-development process of US companies. Wilhelm [35] supports this perspective, pointing to the example of Toyota, which encourages horizontal sharing among its suppliers as a way to improve the whole chain. Wiengarten, Humphreys, Cao, Fynes and McKittrick [24], in their research into the German automotive chain, stress the importance of information quality (especially information that is shared to improve the process) for good collaboration between companies in the chain. Lelis and Simon [36] investigated relationships in the automotive chain in their study of a plastics manufacturer, and support the view of Wiengarten et al. [24]. The results show that efficiency and effectiveness in supply chain management can be hampered by informal communication and by a lack of integrated planning among members.

In Brazil, Vanalle and Salles [37] show that the relationship between the components of the supply chain is closer to an associative model, characterised by long-term contracts and great interdependence. The authors proved that, even though the cost priority is the most important in the automaker's selection of suppliers, the frequency of delivery, the intensity and speed of communication between the companies, and the technical support offered by the automaker to improve the plants of the suppliers demonstrate a high level of confidence between the parties.

However, the difficulties in the theory are also pointed up. Freitas, Tomas and Alcantara [38] note that the collaborative relationship between companies is composed of behavioural, physical, and 
cultural factors, and that the main difficulties observed after the consolidation of cooperative networks lie mainly in behavioural factors and cultural activities. Lélis and Simon [36] contribute to this perspective, emphasising that a company does not normally participate in a single chain but maintains other relationships, making management difficult - especially with more complex products. The authors notice that relationship conflicts between customers and suppliers can occur, creating problems for the chain and reinforcing the importance of strategic alignment among the participants. Bertaglia [39] argues that a collaborative relationship along the chain is the most difficult to create if that relationship is not to be limited simply to a partnership, but rather to become a relationship of mutual trust. Lélis and Simon [36] add that building a trusting relationship does not occur easily, but takes a long time and much dedication on the part of the participants. Henke Jr., Parameswaran and Pisharodi [40] demonstrate, in a survey of the US automotive chain, that the pressure to reduce costs can coexist with a relationship of trust between suppliers. In another paper, Henke Jr., Yeniyurt, and Zhang [41] researched the same automotive chain, and identified which suppliers are willing to accept reduced prices for their products if they forsee future business opportunities. In the automotive segment, the policy of being open about costs between buyer and seller is relatively common, thus making a study of cost reduction easier. Möller, Windolph and Isbruch [42] show that the adoption of an open cost practice depends on the context, and mainly on relational factors such as trust and commitment between partners. On the other hand, Windolph and Moeller [43] show that the disclosure of cost data may leave the supplier company vulnerable to pressure from its customers to reduce the profit margin. Finally, in an approach to institutional perspectives, Sacomano Neto, Truzzi and Kirschbaum [44] observe that the behaviour of actors in a supply chain is related to the set of norms and rules that permeate the relationships of exchange.

In order to organise the theoretical propositions, Table 2 shows these texts and how they relate to the respective authors.

Table 2: Theoretical propositions

\begin{tabular}{|c|c|}
\hline Propositions & Authors \\
\hline $\begin{array}{l}\text { Competitive priorities consist of } \\
\text { translating customer needs. Usually } \\
\text { focus on cost, quality, flexibility, and } \\
\text { delivery. }\end{array}$ & $\begin{array}{l}\text { Jabbour (2009); Peng, Schroeder \& Shah (2011); Thürer, } \\
\text { Godinho Filho, Stevenson \& Fredendall (2013); Gonzales-Benito } \\
\text { \& Gonzales-Benito (2010); Kroes \& Ghosh (2010); Alves Filho, } \\
\text { Nogueira \& Bento (2011); Guimarães, Teodoro Filho, Lara \& } \\
\text { Saltorato (2014). }\end{array}$ \\
\hline $\begin{array}{l}\text { Importance of strategic alignment along } \\
\text { the supply chain. }\end{array}$ & $\begin{array}{l}\text { Sukati, Hamid, Baharun, Alifia \& Anuar (2012); Alves Filho, } \\
\text { Cerra, Maia, Sacomano Neto \& Bonadio (2004); Freitas, Tomas } \\
\text { \& Alcantara (2013). }\end{array}$ \\
\hline $\begin{array}{l}\text { Collaboration along the supply chain, } \\
\text { both between peer companies and } \\
\text { between companies at different levels, } \\
\text { is beneficial to organisations. }\end{array}$ & $\begin{array}{l}\text { Eisenhardt, Furr \& Bingham (2010); Brito \& Mariotto (2013); } \\
\text { Joshi, Nepal, Rathore \& Sharma (2013); Lambert \& Cooper } \\
\text { (2000); Lambert \& Schwieterman (2012); Dyer \& Nobeoka } \\
\text { (2000); Prahinski \& Benton (2004); Rensburg (2012); Wilhelm } \\
\text { (2011); Lélis \& Simon (2013). }\end{array}$ \\
\hline $\begin{array}{l}\text { Difficulties and important characteristics } \\
\text { for effective collaborative relationships } \\
\text { in supply chains. }\end{array}$ & $\begin{array}{l}\text { Lélis \& Simon (2013); Bertaglia (2009); Henke Jr., } \\
\text { Parameswaran \& Pisharodi (2008); Henke Jr., Yeniyurt \& Zhang } \\
\text { (2009); Möller, Windolph \& Isbruch (2011); Windolph \& Moeller } \\
\text { (2012); Sacomano Neto, Truzzi \& Kirschbaum (2013). }\end{array}$ \\
\hline $\begin{array}{l}\text { Changes in the automotive supply chain: } \\
\text { reduction in the number of suppliers, } \\
\text { long-term relationships, and promotion } \\
\text { of integration among suppliers. }\end{array}$ & $\begin{array}{l}\text { Alves Filho, Nogueira \& Bento (2011); Alves Filho, Rachid, } \\
\text { Donadone, Martins, Truzzi \& Vanalle (2002); Wiengarten, } \\
\text { Humphreys, Cao, Fynes \& McKittrick (2010); Bailey (2007); } \\
\text { Pereira \& Geiger (2005); Vanalle \& Salles (2011). }\end{array}$ \\
\hline
\end{tabular}


Considering the research problem and the established objectives, it is concluded that the case study method is the best one to use, given the possibility of studying the phenomenon in its natural environment, and the search for answers to understand the complexity of the problem through observation [45][46]. Based on the exploratory nature of the research and the possibility of investigating several units of analysis (Figure 2 and Table 3 ) within the same problem, a single integrated case study [45] will be used.

Tier 2 suppliers

Tier 1 suppliers

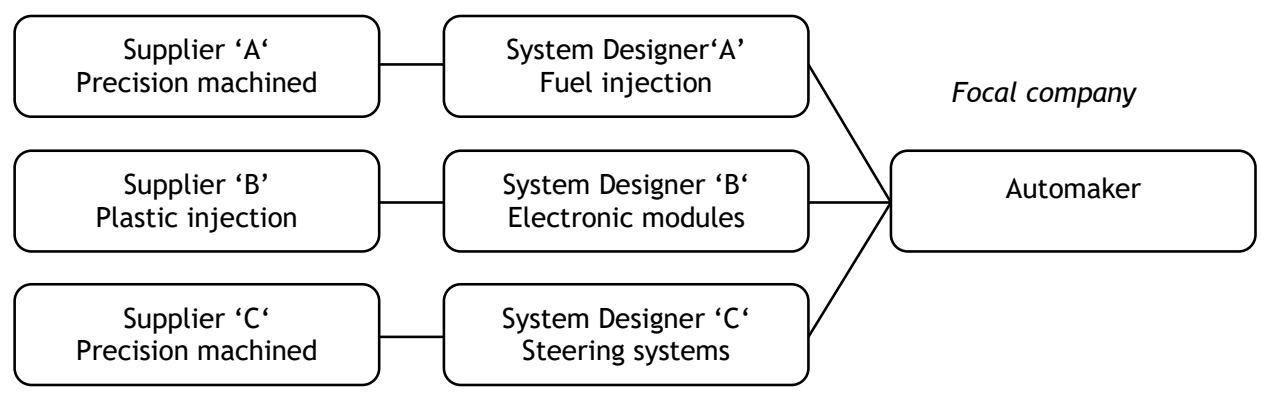

Figure 2: Study objects and analysis units

Table 3: Analysis units

\begin{tabular}{|c|c|c|c|c|c|}
\hline $\begin{array}{l}\text { Analysis } \\
\text { units }\end{array}$ & Main products & Location & $\begin{array}{c}\text { Approximate } \\
\text { length of time in } \\
\text { Brazil }\end{array}$ & $\begin{array}{l}\text { Approximate } \\
\text { number of } \\
\text { employees }\end{array}$ & Interviewed \\
\hline Automaker & Automobiles & $\begin{array}{l}\text { São Paulo } \\
\text { - BR }\end{array}$ & 90 years & 21000 & $\begin{array}{l}\text { Manager of } \\
\text { supplier quality } \\
\text { engineering }\end{array}$ \\
\hline $\begin{array}{c}\text { System } \\
\text { Designer A }\end{array}$ & $\begin{array}{l}\text { Fuel injection } \\
\text { systems }\end{array}$ & $\begin{array}{l}\text { São Paulo } \\
\text { - BR }\end{array}$ & 61 years & 9500 & $\begin{array}{c}\text { Quality assurance } \\
\text { engineer }\end{array}$ \\
\hline $\begin{array}{c}\text { System } \\
\text { Designer B }\end{array}$ & $\begin{array}{c}\text { Electronic } \\
\text { automotive } \\
\text { modules }\end{array}$ & $\begin{array}{l}\text { São Paulo } \\
\text { - BR }\end{array}$ & 66 years & 900 & $\begin{array}{c}\text { Quality assurance } \\
\text { analyst }\end{array}$ \\
\hline $\begin{array}{c}\text { System } \\
\text { Designer C }\end{array}$ & $\begin{array}{l}\text { Steering } \\
\text { systems }\end{array}$ & $\begin{array}{l}\text { São Paulo } \\
\text { - BR }\end{array}$ & 57 years & 5000 & $\begin{array}{c}\text { Quality assurance } \\
\text { engineer }\end{array}$ \\
\hline Supplier A & Machined parts & $\begin{array}{l}\text { São Paulo } \\
\text { - BR }\end{array}$ & 55 years & 980 & $\begin{array}{c}\text { Quality and } \\
\text { engineering } \\
\text { manager }\end{array}$ \\
\hline Supplier B & Plastic parts & $\begin{array}{l}\text { São Paulo } \\
\text { - BR }\end{array}$ & 5 years & 52 & $\begin{array}{c}\text { Director and } \\
\text { quality analyst }\end{array}$ \\
\hline Supplier C & Machined parts & $\begin{array}{c}\text { São Paulo } \\
\text { - BR }\end{array}$ & 12 years & 120 & Quality supervisor \\
\hline
\end{tabular}

In order to carry out this research, semi-structured interviews were conducted with company representatives (Table 3), guided by a research tool that was designed for each level of the chain. In addition to the interview, quality manuals for suppliers, quality standards and standards, performance charts, organisational charts, audit reports, and observed jobs were analysed. Interviews were conducted at each of the companies, in meeting rooms or in the interviewees' work rooms, without the presence of other people. The data were organised into theoretical propositions, comparing the results with the theory being studied. The information was triangulated among the participants of the chain in order to allow an analysis of the units and thus obtain more accurate information, as described by Yin [45]. The validity of the research was checked using the criteria stated by Yin [45] and Voss, Tsikriktsis and Frohich [46]. The criteria were:

- Construct validation: The theoretical construct was elaborated through multiple sources, as described by Yin [45], through collecting papers in international periodicals and in the main 
national academic journals in the areas of production and management engineering. After constructing the research protocol, it was discussed with an experienced researcher in order to adapt it to the objectives of the work.

- External validity: Since a single case with integrated analysis units was studied, it was possible to triangulate and replicate data, as described by Yin [45], and achieve consequent external validation of the results by comparing the data obtained.

- $\quad$ Reliability: As described in this article, the study used a research protocol previously developed and used in all the interviews conducted. The formation of the database was partial, due to the confidential nature of the researched areas.

\section{RESULTS}

\subsection{Alignment and competitive priorities}

All respondents agreed that the most important competitive priority is cost. This is justified by the current global economic scenario, including the low costs of Chinese manufacturers. This situation directly affects the process of selecting, evaluating, and developing suppliers, who regard the competitive priorities of quality and delivery as qualifying criteria, and cost and flexibility as winning criteria. Respondents demonstrated their influence in the purchasing area (which prioritises the lowest cost), saying that suppliers with the potential for greater cost reduction are preferred over suppliers that have equivalent costs but less potential to reduce them. As for the strategic alignment along the chain, all respondents agreed that the customers set the direction. One caveat: in large traditional multinational systems, whose work structures are already established, this influence is significantly less than in the smaller system designers. The interviewees emphasised that the metrics used by the clients to monitor their suppliers, as well as the audit processes, are important indicators of the strategic direction.

Table 4 shows the competitive and metric priorities encountered during the research.

Table 4: Competitive and metric priorities for suppliers

\begin{tabular}{|c|c|c|}
\hline Unit of analysis & Competitive priorities & Metrics for suppliers \\
\hline Automaker & $\begin{array}{l}\text { - Winners: cost, flexibility* and } \\
\text { technology } \\
\text { - Qualifiers: quality (performance and } \\
\text { management systems) and delivery }\end{array}$ & $\begin{array}{c}\text { Quality (performance and } \\
\text { management systems), service } \\
\text { (delivery), technology and price (all } \\
\text { metrics open to suppliers) } \\
\text { Note: Flexibility not measured. }\end{array}$ \\
\hline System designer & $\begin{array}{l}\text { - Winners: cost and flexibility* } \\
\text { - Qualifiers: quality and delivery }\end{array}$ & $\begin{array}{l}\text { Open: Quality (performance and } \\
\text { management systems) and delivery } \\
\text { Strictly in the commercial area: Cost } \\
\text { Note: Flexibility not measured. }\end{array}$ \\
\hline Suppliers & $\begin{array}{l}\text { - Winners: cost and flexibility* } \\
\text { - Qualifiers: quality and delivery }\end{array}$ & $\begin{array}{l}\text { Open: Quality (performance and } \\
\text { management systems) and delivery } \\
\text { Strictly in the commercial area: Cost } \\
\text { and flexibility not measured. }\end{array}$ \\
\hline \multicolumn{3}{|c|}{$\begin{array}{l}\text { *In this case, the competitive priority of flexibility should be understood in terms of the } \\
\text { following dimensions: implement rapid changes in product design; rapid introduction of new } \\
\text { versions of existing or new products; and changes in production volumes in response to changing } \\
\text { demand. }\end{array}$} \\
\hline
\end{tabular}

The identified competitive priorities, although in a different order, are in line with what was identified in the study of Alves Filho, Nogueira, and Bento [22]. However, they differ from the findings of Guimarães, Teodoro Filho, Lara and Saltorato [30]. The results show that the current competitive priorities of the chain are strongly cost-oriented, followed by quality, punctuality, and flexibility, according to the interviewees, due to the current economic situation. Quality and timeliness of delivery were classified as 'qualifying criteria', unlike cost and flexibility (which reflect the final decision about the purchase), which were classified as criteria for winning an order. This result refers to the findings of Vanalle and Salles [37], which indicate that price is the competitive differential in the automotive chain. Stated broadly, it can be concluded that, while the priorities of quality and punctuality of delivery still represent a significant degree of competitiveness, they are not more important than cost. It should be mentioned that, according to the system designers who were interviewed, Japanese automakers are also targeting cost. However, unlike US automakers, Japanese automakers tend to maintain a long-term relationship, reducing the risk of 
the supplier being replaced without considering its track record of good performance. Such a view confirms Kim's [4] propositions.

Still on costs, the research into this priority refers to the propositions of Henke Jr., Yeniyurt, and Zhang [41], who describe suppliers implementing cost reductions for the sake of future business. However, the policy of 'open costs' practised by suppliers ' $A$ ' and ' $B$ ' proved the vulnerability of their profit margins, according to the interviewees, confirming the propositions of Windolph and Moeller [43]. In all the interviews conducted, the competitive priority 'flexibility' was always mentioned by the researcher, but not by the interviewee. According to the interviewees, this criterion is considered when there is a tie between the other competitive priorities, or in cases of product development that require such a stance from the supplier. However, it is an order-winning criterion, not a qualifying one.

\subsection{Relationship between companies in the chain}

The relationship between the companies in the automotive chain basically occurs through product development activities, processes, analysis and audits of products and processes, and the implementation of improvements. This relationship differs, depending on the level occupied by the company in the chain; and it is always directly related to the competitive priorities represented by the performance metrics used. The relationship between the automaker and its system designers occurs in a more structured way, with the assembler being proactive in developing its suppliers. This development occurs through training in management methods and in the follow-up of product and process development. The assembler interviewed has a methodology of supplier development that is structured along two lines: the application of the advanced product quality planning (APQP) method for product and process development, and the application of a basic quality system (BQS), directed to production management techniques. This programme, according to the interviewee, has been occurring mainly in the search for new suppliers and reduced costs. Usually new suppliers with more competitive costs do not have the same infrastructure as the traditional suppliers, implying that the basic requirements for obtaining quality and punctuality of delivery may not be achieved. In addition to these tools, the automaker performs constant and programmed audits of its product, process, and management systems to encourage its suppliers to perform better. The initiatives to exchange knowledge among suppliers are still embryonic for the automaker who was interviewed. When asked whether the relationship between the automaker and its suppliers could be characterised as a 'win-win' relationship, the respondent acknowledged that, despite attempts to have the partnership within the chain stimulated effectively, the drastic cost reduction policy did not allow that assessment of the relationship to be fully applied.

The system designer's approach to second-tier suppliers is different from that of the automaker. Systems $A$ and C keep their supplier quality engineer (EQF) constantly present at the supplier company. Periodic training is offered to the supplier, usually related to quality improvement and cost reduction. The exchange of experience takes place informally, and horizontal exchanges between suppliers are not encouraged. Sporadic audits of product and process are carried out. System designer B acts less proactively with the supplier. The activities of the responsible professional are summarised in the follow-up of new developments and audits. All system interviewees agree that there is a 'win-win' relationship in partnership with their suppliers, due to the trade policies that foster partnerships with strategic suppliers. Second-tier providers see this relationship differently. In the view of all the interviewees, there is no partnership relationship, but rather a programme to collect and monitor performance metrics (quality and delivery) in addition to the pressure to reduce costs. The mediating role of strategic alignment and competitive priorities in the relationship processes along the automotive chain is clearly evident.

The results clearly demonstrate the strategic alignment, in line with what was perceived by Guimarães, Teodoro Filho, Lara and Saltorato [30]. As mentioned earlier, Sukati, Hamid, Baharun, Alifiah and Anuar [19] reaffirm the importance of this alignment in achieving competitive advantage. The results also show that all companies recognise the importance of the supply chain acting in an integrated way to achieve good results, confirming the theoretical propositions. This integration occurs through a focal company (assembler) seeking the integration of key processes, reinforcing the perspective of Lambert and Cooper [1]. There is a tendency for companies to act in an associative way, as predicted by Vanalle and Salles [37], through a high level of interdependence and a vision to commit to long-term contracts; but this last item is not yet a reality in the researched 
network. The automaker interviewed partially confirmed the theoretical propositions of Kim [4], keeping in mind the adoption of worldwide vehicle platforms, the valuation of the national subsidiary, the reduction in the number of suppliers, and supplier development activities. However, closer supplier relationships and the promotion of long-term relationships are mediated by supplier cost. Because of the constant search for lower costs, the automaker interviewed does not have this kind of long-term relationship with suppliers. However, it is important to notice that, on the initiative of the Brazilian subsidiary, work is being done to find and develop strategic suppliers with long-term objectives, confirming that there is at least the intention to overcome what the theory already proposes as a difficulty.

Going back to the outsourcing processes, the second-level suppliers - the focus of this research are also suffering from the impact of this process. Assembly activities have been delegated to suppliers that previously only manufactured, along with a more active participation in production planning, logistics, and product development routines, confirming Bailey's [27] proposals. Within this process (including this research, involving suppliers ' $B$ ' and ' $C$ '), small and medium-sized enterprises (SMEs) emerge. Attracted by the volume of production and the possibility of having the automotive industry in their portfolio of clients, these companies begin to be more effective as second-level suppliers, according to Pereira and Geiger [28]. With regard to the partnership processes, the three system designer have identified that, as with Japanese automakers, long-term contracts and development processes better ensure better results in terms of quality and productivity, confirming the propositions of Prashinski and Benton [32], Dyer and Nobeoka [31], and Wilhelm [35]. However, these same systemists still cannot apply the same kind of evaluation to their suppliers. What works against this opportunity is that the suppliers do not see, in any circumstance, a relationship of cooperation or 'win-win'. Specifically with respect to supplier 'A', Dyer and Nobeoka [31] affirm that there may be a need for cultural and organisational improvements so that the results of the partnership with the client are seen in a better light. The results show that secondlevel suppliers are heavily influenced by their customers in strategic terms. These results confirm Rensburg's [33] theories, which outline the advantages for small and medium-sized companies of exchanging knowledge with large companies.

\section{FINAL CONSIDERATIONS}

The results partially confirm the theoretical propositions, demonstrating that there is a strategic alignment in the automotive chain, and that clients have a great strategic influence on their suppliers - although better-structured suppliers experience this influence less intensely than unstructured suppliers do. The strategy migrates from one level to another in the chain through the competitive priorities established by the customers. The identified competitive priorities are different between the automaker and the system designer, and between second-level suppliers and the system designer. However, in both cases, cost and flexibility are order-winning criteria, and quality and timeliness of delivery are qualifying criteria. In addition to these, the automaker looks for suppliers with technological potential. These competitive priorities directly influence the configurations of the relationship between the companies in the automotive supply chain. As far as the relationship process is concerned, the results show that there is already a degree of maturity between the automaker and the system designer who were surveyed, and that it is slowly moving towards a closer cooperation and integration between the activities. However, due to the heavy pressure to reduce costs, the effective partnership relationships that are planned in theory have been adversely affected. It has already been noted that, when this same analysis is applied to the relationship between system designer and second-level suppliers, there is no building of effective partnerships, mainly due to the heavy pressure to reduce costs, and the resultant perception of second-tier suppliers that only the automakers and system designer gain from it. In short, it can be confirmed that relationships within the automotive supply chain are still based on what the customer demands and on competitive priorities, and are still far from being effective models of partnership. This scenario shows that, in spite of the theoretical view - that is, the tendency of the supply chain to act as a network of companies that cooperate - the research reveals that this movement needs to be worked on more effectively, especially with second-level suppliers. The conditions envisaged by the theory, such as long-term contracts and mutual benefits, have not yet reached this level of the chain, mainly because of cost-reduction processes.

The results of this research have only a limited capacity for generalisation, given the qualitative nature of the research, together with the number of cases studied. Future research could analyse a 
larger sample to confirm these results, extend the model to other supply chains, and analyse more deeply the precariousness of relationships when the pursuit of cost reductions is so dominant.

\section{REFERENCES}

[1] Lambert, D.M. \& Cooper, M.C. 2000. Issues in supply chain management. Industrial Marketing Management, 29(1), pp. 65-83.

[2] Kroes, J.R. \& Ghosh, S. 2010. Outsourcing congruence with competitive priorities: Impact on supply chain and firm performance. Journal of Operations Management, 28(2), pp. 124-143.

[3] National Association of Motor Vehicle Manufacturers. 2017. Yearbook. São Paulo: Anfavea.

[4] Kim, S.W. 2009. An investigation on the direct and indirect effect of supply chain integration on firm performance. International Journal of Production Economics, 119(2), pp. 328-346.

[5] Aggarwal, V.A., Siggelkow, N. \& Singh, H. 2011. Governing collaborative activity: Interdependence and the impact of coordination and exploration. Strategic Management Journal, 32(7), pp. 705-730.

[6] Boaventura, J.M.G. \& Fischmann, A.A. 2003. Estudo dos conceitos sobre o conteúdo da estratégia: Uma ilustração no campo da tecnologia da informação. São Paulo: University of São Paulo.

[7] Porter, M.E. 1996. What is strategy? Harvard Business Review, 74(6), pp. 61-78.

[8] Wheelen, T.L. \& Hunger, J.D. 2004. Concept in strategic management and business policy. Singapore: Pearson Education.

[9] Almeida, F.C., Machado Neto, A.J. \& Giraldi, J.M.E. 2006. Structure and strategy: Evolution of paradigms. Revista de Gestão, 13(2), pp. 15-26.

[10] Mintzberg, H., Lampel, J., Quinn, J.B. \& Ghoshal, S. 2006. O processo da estratégia: Conceitos, contextos e casos relacionados. Porto Alegre: Bookman.

[11] Chase, R.B., Jacobs, F.R. \& Aquilano, N.J. 2006. Administração da produção para vantagem competitiva. Porto Alegre: Bookman.

[12] Skinner, W. 1969. Manufacturing - missing link in corporate strategy. Harvard Business Review, May/June, pp. 156-167.

[13] Jabbour, A.B.L.S. 2009. Prioridades competitivas da produção e práticas de gestão da cadeia de suprimentos: Uma survey no setor eletrônico brasileiro. Doctoral thesis, Federal University of São Carlos, Brazil.

[14] Thürer, M., Godinho Filho, M., Stevenson, M. \& Fredendall, L.D. 2013. Competitive priorities of small manufacturers in Brazil. Industrial Management \& Data Systems, 113(6), pp. 856-874.

[15] Peng, D.X., Schroeder, R.G. \& Shah, R. 2011. Competitive priorities, plant improvement and innovation capabilities, and operational performance: A test of two forms of fit. International Journal of Operations \& Production Management, 31(5), pp. 484-510.

[16] González-Benito, J. \& González-Benito, 0. 2010. A study of determinant factors of stakeholder environmental pressure perceived by industrial companies. Business Strategy and the Environment, 19(3), pp 164-181.

[17] Hill, T. 1993. Manufacturing strategy: The strategic management of the manufacturing function ( $2^{\text {nd }}$ ed.). Basingstoke: Macmillan.

[18] Eisenhardt, K.M., Furr, N.R. \& Bingham, C.B. 2010. Crossroads - microfoundations of performance: Balancing efficiency and flexibility in dynamic environments. Organization Science, 21(6), pp. 1263-1273.

[19] Sukati, I., Hamid, A.B.A., Baharun, R., Alifiah, M.N. \& Anuar, M.A. 2012. Competitive advantage through supply chain responsiveness and supply chain integration. International Journal of Business and Commerce, 1(7), pp. 1-11.

[20] Alves Filho, A.G., Cerra, A.L., Maia, J.L., Sacomano Neto, M. \& Bonadio, P.V.G. 2004. Pressupostos da gestão da cadeia de suprimentos: Evidências de estudos sobre a indústria automotiva. Gestão \& Produção, 11(3), pp. 275-288.

[21] Brito, E.P.Z. \& Mariotto, G. 2013. Benefits of cooperation between buyers and providers: A study in the field of information and communication technology. Revista Brasileira de Gestão de Negócios, 15(47), pp. 241-261.

[22] Alves Filho, A.G., Nogueira, E. \& Bento, P.E.G. 2011. Análise das estratégias de produção de seis montadoras de motores para automóveis. Gestão e Produção, 18(3), pp. 603-618.

[23] Lockstrom, M., Schadel, J., Moser, R. \& Harrison, N.J. 2010. Successful supplier integration in the Chinese automotive industry: A theoretical framework. International Journal of Integrated Supply Management, 5(3), pp 260-283.

[24] Wiengarten, F., Humphreys, P., Cao, G., Fynes, B. \& McKittrick, A. 2010. Collaborative supply chain practices and performance: Exploring the key role of information quality. Supply Chain Management: An International Journal, 15(6), pp. 463-473.

[25] Joshi, D., Nepal, B., Rathore, A.P.S. \& Sharma, D. 2013. On supply chain competitiveness of Indian automotive component manufacturing industry. International Journal of Production Economics, 143(1), pp. 151-161.

[26] Alves Filho, A.G., Rachid, A., Donadone, J.C., Martins, M.F., Truzzi, O.M.S. \& Vanalle, R.M. 2002. Manufacturing strategies and work organization in an engine supply chain. Revista de Administração de Empresas Eletrônica, 1(2), pp. 2-10. 
[27] Bailey, D. 2007. Globalization and restructuring in the auto industry: The impact on the West Midlands automobile cluster. Strategic Change, 16(4), pp. 137-144.

[28] Pereira, G.M. \& Geiger, A. 2005. Product complexity and production volumes as determining factors of small and medium-sized automotive supplier development strategies. Gestão e Produção, 12(2), pp. 191201.

[29] Lambert, D.M. \& Schwieterman, M.A. 2012. Supplier relationship management as a macro business process. Supply Chain Management: An International Journal, 17(3), pp. 337-352.

[30] Guimarães, M.R.N., Teodoro Filho, A.M., Lara, F.F. \& Saltorato, P. 2014. Manufacturing strategy in the auto parts industry: A multicase study in companies in the Sorocaba region. Produção on-line, 14(2), pp 499-532.

[31] Dyer, J.H. \& Nobeoka, K. 2000. Creating and managing a high-performance knowledge-sharing network: the Toyota case. Strategic management journal, pp.345-367.

[32] Prahinski, C. \& Benton, W.C. 2004. Supplier evaluations: Communication strategies to improve supplier performance. Journal of Operations Management, 22(1), pp. 39-62.

[33] Rensburg, S.M. 2012. The influence of interorganisational relationships on the competitiveness of small and medium enterprises. Doctoral thesis, University of Johannesburg, South Africa.

[34] Dyer, J.H. \& Hatch, N.W. 2004. Using supplier networks to learn faster. MIT Sloan Management Review, $45(3)$, p. 57.

[35] Wilhelm, M.M. 2011. Managing competition through horizontal supply chain relations: Linking dyadic and network levels of analysis. Journal of Operations Management, 29(7), pp. 663-676.

[36] Lélis, E.C. \& Simon, A.T. 2013. Relationship management in the plastic parts industry of the automotive chain. Gestão \& Produção, 20(4), pp. 889-911.

[37] Vanalle, R.M \& Salles, J.A.A. 2011. Relationship between assemblers and suppliers: Theoretical models and case studies in the Brazilian auto industry Gestão \& Produção, 18(2), pp. 237-250.

[38] Freitas, D.C., Tomas, R.N. \& Alcantara, R.L.C. 2013. Vendor managed inventory (VMI): Analysis of barriers and critical success factors in large companies. Revista de Administração da Unimep, 11(3), pp. 221-253.

[39] Bertaglia, P.R. 2009. Logística e Gerenciamento da Cadeia de Abastecimento (2 ${ }^{\text {nd }}$ ed.). São Paulo: Saraiva.

[40] Henke Jr., J.W., Parameswaran, R. \& Pisharodi, R.M. 2008. Manufacturer price reduction pressure and supplier relations. Journal of Business \& Industrial Marketing, 23(5), pp. 287-300.

[41] Henke Jr., J.W., Yeniyurt, S. \& Zhang, C. 2009. Supplier price concessions: A longitudinal empirical study. Marketing Letters, 20(1), pp. 61-74.

[42] Möller, K., Windolph, M., \& Isbruch, F. 2011. The effect of relational factors on open-book accounting and inter-organizational cost management in buyer-supplier partnerships. Journal of Purchasing and Supply Management, 17(2), pp. 121-131.

[43] Windolph, M. \& Möller, K. 2012. Open-book accounting: Reason for failure of inter-firm cooperation? Management Accounting Research, 23(1), pp. 47-60.

[44] Sacomano Neto, M., Truzzi, M.S., Kirschbaum, C. 2013. Isomorphism and institutional control in a modular plant of the automotive industry. Revista Brasileira de Gestão de Negócios, 15(49), pp. 524-544.

[45] Yin, R.K. 2010. Estudo de caso: Planejamento e métodos (4 $4^{\text {th }}$ ed.). Porto Alegre: Bookman.

[46] Voss, C., Tsikriktsis, N. \& Frohlich, M. 2002. Case research in operations management. International Journal of Operations \& Production Management, 22(2), pp. 195-219. 